\title{
Chromosome Analyses of Embryos Sired by Bulls Heterozygous for the 7/21 Robertsonian Translocation
}

\author{
Hirofumi Hanada*, Masaya Geshi, Minoru Sakaguchi \\ and Miharu YONAI \\ Tohoku National Agricultural Experiment Station, \\ Morioka-shi 020-01 \\ * Present Adress : National Institute of Animal Industry, \\ Tsukuba Norinkenkyu danchi, Ibaraki-ken 305
}

(Received May 18, 1993)

Key words : 7/21 translocation, Bovine embryo analysis

The Robertsonian translocation is the most frequent chromosome aberration in cattle. The $1 / 29$ and the $7 / 21$ Robertsonian translocations have been observed in Japanese Black Cattle until now ${ }^{3,15,16)}$, and the $1 / 29$ translocation has been reported in many breeds throughout the world ${ }^{6)}$. Analyses of breeding data have suggested that the $1 / 29$ translocation causes a slight reduction in fertility ${ }^{4,17,20)}$. Low fertility has been ascribed to the early death of unbalanced embryos ${ }^{12,19,22)}$. On the other hand, the $7 / 21$ translocation has not been reported in other breeds. Though the meiotic study of heterozygous bulls has indicated the formation of unbalanced cells from malsegregation ${ }^{8)}$, the effect of the $7 / 21$ translocation on fertility is still unknown. To determine its effect on fertility, it is necessary to ascertain whether monosomic and trisomic embryos result from the fertilization of unbalanced gametes. The prosent paper is concerned with the chromosome analyses of embryos sired by normal and heterozygous bulls regarding the 7/21 trans- location.

\section{Materials and Methods}

Scmen samples for in vitro fertilization were obtained from four Japanese Black bulls. Two of the bulls were heterozygotes in regard to the $7 / 21$ translocation. Sperm capacitation, insemination and culture of fertilized ova were carried out by the modification of a procedure described previously ${ }^{5)}$. A total of 130 earlyand expanded blastocytes were prepared for chromosome analyses. They were collected 6 to 8 days after in vitro fertilization (Day 0), and were continuously cultured in TCM 199 medium containing $0.06 \mu \mathrm{g} / \mathrm{ml}$ of vinblastine sulfate (Aldrich) for 14 hours. The chromosome preparations were made according to a modification of the technique of KAMIGUCHI and MrKaMo ${ }^{11)}$. At first, embryos were treated with $0.5 \%$ pronase (Wako Pure Chemical Industries) for 60 seconds to remove the zona pellucida. Then they were placed in $0.8 \%$ sodium citrate hypotonic solution con-

$7 / 21$ 口ハートソン型本公座へテロ種雄牛由来の胚の染色体分析：花田博文・下司雅也・坂口 実・米内美晴（農林 水産省東北戉業試験埸，盛润市 020-01)

Anim. Sci. Technol. (Jpn.) 64 (12) : 1178-1181 1178 
taining $3 \%$ fetal calf serum for 60 minutes at $20^{\circ} \mathrm{C}$. The chromosome slides were prepared using the gradual fixation-air dry method. The first fixation was carried out by placing embryos in a mixed solution of methanolacetic acid-distilled water $(5: 1: 4)$ for 5 minutes. Then embryos were fixed on a slide by dropping a mixture of methanol-acetic acid $(3: 1)$. Finally, the slides were immersed in a mixture of methanol-acetic acid-distilled water $(3: 3: 1)$ for 5 minutes. The air-dried chromosome preparations were stained with $2 \%$ Giemsa solution for 20 minutes and their karyotypes were analysed.

\section{Results and Discussion}

The chromosome analyses were carried out on 130 early and expanded blastocysts, of which 49 were embryos fertilized with semen from normal bulls and 81 were those sired by the $7 / 21$ translocation heterozygous bulls. The results are shown in Table 1. In the group sired by normal bulls, 23 embryos had metaphase spreads which could be confidently analysed. All the analysable embryos showed normal chromosome complements, $2 \mathrm{n}=60, \mathrm{XY}$ and $2 \mathrm{n}=60, \mathrm{XX}$.

A total of 36 embryos were suitable for chromosome analyses in the group sired by the

Table 1. Chromosome analyses of embryos sired by the normal and heterozygous bulls for the $7 / 21$ translocation

\begin{tabular}{lcc}
\hline \multirow{2}{*}{ No. of embryos } & \multicolumn{2}{c}{ Karyotype of sire } \\
\cline { 2 - 3 } & Normal & Hetero. \\
\hline Processed (A) & 49 & 81 \\
Analyzed (B) & 23 & 36 \\
Balanced & & \\
Normal & 23 & 19 \\
Hetero. & - & 15 \\
Unbalanced & - & - \\
Monosomy & - & 2 \\
Trisomy & 46.9 & 44.4 \\
B/A (\%) & & \\
\hline
\end{tabular}

$7 / 21$ translocation heterozygous bulls. Of these embryos, 19 had normal chromosome complements and 15 were embryos balanced with 59 chromosomes including the 7/21 translocation chromosome. However, 2 (5.6\%) were trisomic embryos with the unbalanced karyotype, $2 \mathrm{n}=60, \mathrm{XY}, \mathrm{t}$ and $2 \mathrm{n}=60, \mathrm{XX}, \mathrm{t}$. These embryos were derived from two different cows and sired by the carrier bull, S 120 .

In the meiotic study of heterozygous bulls in regard to the 1/29 Robertsonian translocation, unbalanced secondary spermatocytes were observed with frequencies of $6.4 \%{ }^{13)}$ and 11.2 $\%{ }^{183}$. The $1 / 29$ translocation seemed to cause a slight reduction in fertility of the carrier bulls ${ }^{4}$ and daughters sired by the heterozygous bulls ${ }^{17,20)}$. This was ascribed to the early death of trisomic and monosomic embryos resulting from adjacent segregation of the trivalent chromosome at the first division ${ }^{12,19,22 \text { ) }}$.

Contrary results have been obtained in sheep. A study on heterozygous rams revealed the presence of aneuploid secondary spermatocytes $^{3}$. However, the cytogenetic study of embryos found no chromosomally unbalanced preimplantation blastocytes ${ }^{14)}$. Extensive studies have suggested that the presence of Robertsonian translocations has no significant effect on fertility ${ }^{1,2}$, and aneuploid cells seem to be eliminated during spermatogenesis in the carrier animals ${ }^{21}$.

Analyses of breeding data concerning the $7 / 21$ heterozygous females failed to detect any decrease in fertility as compared with females with a normal karyotype ${ }^{9)}$. However, a meiotic study revealed a higher incidence of hypermordal cells in bulls which were heterozygous in regard to the $7 / 21$ translocation ${ }^{8)}$. The percentage of non-disjunction calculated by the frequency of the hyperhaploid cells was $7.9 \%$ in the heterozygous state versus $2.3 \%$ in the normal bulls ${ }^{10)}$. Trisomic embryos, presumably resulting from the fertilization of normal ova by hyperhaploid spermatozoa, were found in the present study. These results suggest 
that the $7 / 21$ translocation in the heterozygous state may be associated with a slight reduction in fertility.

Chromosome analyses could not be successfully performed on more than half of the embryos. The failure was mainly due to clumping of cells, insufficient spreading of chromosomes and their excessive overspreading. Some embryos had no metaphase cells. Improvement in the techniques of hypotonic treatment and fixation is essential to obtain high quality metaphase spreads. Furthermore, it is important to determine the optimum concentration and duration of vinblastine treatment in order to accumulate numbers of analyzable metaphases for each embryo.

\section{References}

1) Bruère, A.N. and H.M. Chapman, Double translocation heterozygosity and normal fertility in domestic sheep. Cytogenet. Cell Genet., 13 : 342-351. 1974.

2) Bruère, A.N., I.S. Scott and L.M. Henderson, Aneuploid spermatocyte frequency in domestic sheep heterozygous for three Robertsonian translocations. J. Reprod. Fert., 63 : 61-66. 1981.

3) Chapman, H.M and A.N. Bruère, The frequency of aneuploidy in the secondary spermatocytes of normal and Robertsonian translocation-carrying rams. $J$. Reprod. Fert., 45: 333-342. 1975.

4) Dyrendahl, I. and I. Gustaysson, Sexual functions, semen characteristics and fertility of bulls carrying the $1 / 29$ chromosome translocation. Hereditas, 90 : 281-289. 1979.

5) Geshi, M., M. Yonai, H. Hanada, T. KOMIYAMA and M. TAKAHASHI, Effect of serum on the in vitro development of bovine embryos derived from in vitro maturation and fertilization. Anim. Sci. Technol. (Jpn.), 64: 480-483. 1993.

6) Gustausson, I., Distribution and effects of the 1/29 Robertsonian translocation in cattle. J. Dairy Sci., 62: 825-835. 1979.

7) Hanada, H., S. Muramatsu, T. Abe and T. Fukushima, Robertsonian chromosome polymorphism found in a local herd of the Japanese Black cattle. Ann Génét. Sél. anim., 13 : 205-211. 1981.
8) Hanada, H. and S. Muramatsu, A sutdy of meiotic chromosomes in Japanese Black bulls carrying the 7/21 Robertsonian translocation. Jpn. J. Zootech. Sci., 60 : 590-595. 1989.

9) Hanada, H., Y. Nagamine, M. Higuchi, S. Muramatsu and T. Fukushima, The incidence of the Robertsonian translocation and its effect on fertility in the Japanese Black cattle. Anim. Sci. Technol. (Jpn.), 62: 540-545. 1991.

10) Hanada, H., M. Higuchi, Y. Nagamine, M. Geshi and S. Muramatsu, Significance of the 7/21 Robertsonian translocation in the Japanese Black cattle. Proc. 10th Eur. Colloq. Cytogenet. Domest. Anim., Utrecht, 78-83. 1993.

11) Kamiguchi, $Y$ and $K$. Mikamo, An improved, efficient method for analyzing human sperm chromosomes using zonafree hamster ova. Am. J. Hum. Genet., 38. 724-740. 1986.

12) King, W.A., T. Linares, I. Gustavsson and A. BANE, Presumptive translocation type trisomy in embryos sired by bulls heterozygous for the $1 / 29$ translocation. Hereditas, 92 : 167-169. 1980.

13) Logue, D.N. and M.J.A. Harvey, Meiosis and spermatogenesis in bulls heterozygous for a presumptive 1/29 Robertsonian translocation. J. Reprod. Fert., 54: 159165. 1978.

14) LoNG, S.E., Cytogenetic examination of pre-implantation blastocyts of ewes mated to rams heterozygous for Massey $I\left(t_{1}\right)$ translocation. Cytogenet. Cell Genet., 18 : 82-89. 1977.

15) Masuda, H., T. Takahashi, A. Soejma and $Y$. WAIDE, Centric fusion of the chromosomes in a Japanese Black bull and his offsprings. Jpn. J. Zootech. Sci., 49 : 853-858. 1978.

16) Masuda, H., Y. Shioya and T. Fukuhara, Robertsonian translocation in Japanese Black Cattle. Jpn. J. Zootech. Sci., 51: 26-32. 1980.

17) Maurer, R.R. and D.W. Vogt, Decreased fertility in related females heterozygous for the $1 / 29$ chromosome translocation. Theriogenology, 30 : 1149-1157. 1988.

18) Popescu, C.P., A study of meiotic chromosomes in bulls carrying the 1/29 translocation. Ann. Biol. anim. Bioch. Bio- 
Embryos Sired by Translocation Buils

phys., 18: 383-389. 1978 .

19) Popescu, C.P., Cytogenetic study on embryos sired by a bull carrier of $1 / 29$ translocation. Proc. 4th Eur. Colloq. Cytogenet. Domest. Anim., Uppsala, 182186. 1980.

20) Refsdat, A.O., Low fertility in daughters of bulls with $1 / 29$ translocation. Acta Vet. Scand., $17:$ 190-195. 1976.
21) Scotr, I.S.A. and A.N. Brukre, Distribution of heterozygous translocations and aneuploid spermatocyte frequency in domestic sheep. J. Hered., 78: 37-40. 1987.

22) WILSON, T.D., Monosomy and trisomy in bovine embryos sired by bulls heterozygous for the $1 / 29$ Robertsonian translocation chromosome. Theriogenology, $\mathbf{3 6}$ : 789-793. 1991. 